Copyright (C) 2021 by Cherkas Global University

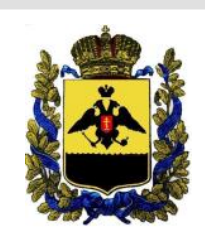

Published in the USA

Bylye Gody

Has been issued since 2006.

E-ISSN: 2310-0028

2021. 16(4): 1910-1921

DOI: $10.13187 /$ bg.2021.4.1910

Journal homepage:

https://bg.cherkasgu.press

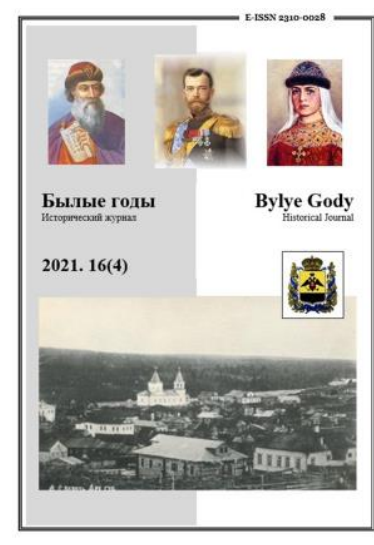

\title{
From the History of Ensuring the Rights of Prisoners in Prisons of the Russian Empire at the turn of the 19th - 2oth centuries (based on materials from the Saratov Province)
}

\author{
Aleksander E. Epifanov a , b , *, Evgeniya M. Pavlenko a \\ a Moscow City University, Moscow, Russian Federation \\ b Volgograd Institute of Management - branch of RANEPA, Volgograd, Russian Federation
}

\begin{abstract}
The formation of a culture of human rights in the Russian Federation is faced with difficulties, which can be overcome only by relying on an in-depth analysis of the historical development of the concept of human rights in Russian society. An important stage in this development was the turn of the late 19th early 2oth centuries, however, due to the lack of a holistic concept of human rights during this period, changes in ideas about the dignity of an individual, his rights and freedoms were reflected primarily in normative legal acts focused on practical application in specific situations. The system for the execution of punishments, which requires the most detailed regulation of its activities, is an object on the example of which changes in ideas about the personality are especially noticeable.

From a historical and legal standpoint, the article reveals the regulation and practice of ensuring the rights of prisoners in Russian penitentiary institutions at the turn of the 19th - 2oth centuries on the example of the Saratov province, with an emphasis on human rights of the "second generation", which in the second half of the 19th century acquired special relevance in Russia.

The article was prepared on the basis of extensive literature, as well as departmental regulations and archival materials, many of which were introduced into scientific circulation for the first time. The article uses general scientific (analysis, synthesis, dialectical method of scientific knowledge, systems approach) and specific scientific (historical) research methods.

It is concluded that this period, despite the specific historical conditions of the socio-economic, managerial and value nature, is characterized by the deepening and development in Russian society of ideas about human rights and the responsibility of the state for their observance.

Keywords: rights of prisoners, prisoners, convicts, Main prison administration, prison committees, Russian Empire, Saratov province.

\section{1. Введение}

Развитие культуры прав человека в разных странах опирается на специфику их исторического развития и, следовательно, происходит не только с различной скоростью, но и с различными приоритетами. В то же время особенности опыта каждой страны в данной сфере составляют наследие всего человечества, так как могут оказаться полезными в сходных условиях и ситуациях. Задача как историков, так и правоведов - систематизировать и обобщить данный опыт и сделать из него правильные выводы.

Одним из исторически значимых направлений развития культуры прав человека в России является гуманизация пенитенциарной системы. Особую актуальность данный вопрос приобрел в Российской империи на рубеже XIX-XX веков, в период, когда была осуществлена попытка капиталистической модернизации всех сфер жизни российского общества, следствием которой стало
\end{abstract}

${ }^{*}$ Corresponding author

E-mail addresses: mvd_djaty@mail.ru (A.E. Epifanov), PavlenkoEM@mgpu.ru (E.M. Pavlenko) 
отделение от крестьянской общины с ее неизменным укладом, основанным на обычном праве, значительного числа свободных индивидов, что часто приводило, в первую очередь в городах, к их десоциализации и, как следствие, нередко к тюремному заключению.

Существенно важным представляется тот факт, что в указанный период расширение прав заключенных, как и вообще прав человека, происходило в России не в контексте заимствования или самостоятельного развития идей и тенденций, свойственных «пионерам» капиталистической трансформации, а на основе глубокого осознания традиций национальной культуры, что, вероятнее всего, является общим фактором для целого ряда «догоняющих», или в современной терминологии «развивающихся» обществ.

\section{2. Материалы и методы}

В качестве эмпирического материала авторами был использован широкий круг разнообразных источников, в том числе обширная литература, имеющаяся по теме, и ведомственные нормативные акты. Основное внимание при подготовке статьи было уделено архивным материалам, многие из которых были введены в научный оборот впервые. В фонде № 446 Государственного архива Саратовской области (Саратов, Российская Федерация) хранятся служебные документы Саратовской губернской тюрьмы и исправительно-арестантского отделения № 2 Тюремного отделения Саратовского губернского правления за период 1803-1918 гг. Фонд № 655 ГАСО «Тюремное отделение Саратовского губернского правления» содержит аналогичные материалы за $1890-1917$ гг. В значительной степени они дублируются в фондах № 290 Камышинской и № 161 Царицынской уездных тюрем (1867-1917 гг.) Государственного архива Волгоградской области (Волгоград, Российская Федерация), по территориальности также обслуживавших Саратовскую губернию и подчинявшихся органам ее управления.

Еще одной важной группой источников, позволивших раскрыть затронутую тему, явились опубликованные собрания документов, а также отдельные нормативные акты и отчетность, касающиеся организации и деятельности дореволюционных пенитенциарных учреждений. В частности, были использованы Свод законов Российской империи (том четырнадцатый); уставы о паспортах, предупреждении преступлений, цензуре, о содержащихся под стражей и ссыльных СПб., 1890 (Свод..., 1890); собрание узаконений и распоряжений правительства № 49 от 22 мая 1890 г. (Собрание..., 1890); сборник циркуляров, изданных по Главному тюремному управлению в 1879-1910 гг. Ч. 1. СПб, 1911 (Сборник..., 1911); Отчет по Главному тюремному управлению за 1902 год. СПб, 1904 (Отчет, 1904); Тюремные вестники 1910. № 3 (Тюремный вестник, 1910) и 1916. № 6-7 (Тюремный вестник, 1916); Общая тюремная инструкция. Утверждена Министром юстиции 28 декабря 1915 г. Пг, 1916 (Общая..., 1916).

В статье используются общенаучные (анализ, синтез) и частнонаучные (исторический) методы исследования. Анализ архивных документов позволил обобщить материал, сопоставить его с историей развития России в соответствующий период и на основе полученных новых данных сделать вывод о постепенном формировании зачатков культуры прав человека в российском обществе. Системный подход обеспечил возможность выделить из общей структуры изучаемых государственноправовых явлений отдельные существенные признаки и неповторимые особенности российского государства и его правовой системы. Также в работе применяется общенаучный диалектический метод научного познания, позволивший рассматривать процессы реформирования пенитенциарной системы Российской империи в их единстве и противоречивости.

\section{3. Обсуждение}

В Российской империи тюрьмоведение традиционно рассматривалось в качестве составной части уголовного права. Именно с этих позиций подходили к организации и деятельности пенитенциарных учреждений крупнейшие дореволюционные отечественные правоведы Н.С. Таганцев (Таганцев, 1902), И.Я. Фойницкий (Фойницкий, 1884) и др. Такие российские ученые, как В.Н. Никитин (Никитин, 1880), С.В. Познышев (Познышев, 1915), Д.А. Линев (Линев, 1880), Н. Николаевский (Николаевский, 1898), Н.М. Ядринцев (Ядринцев, 1872), С.К. Гогель (Гогель, 1897), М.И. Красовский (Красовский, 1900), предпринимали попытки раскрыть, в основном с позиций истории отечественного права, становление и развитие российской пенитенциарной системы, а также связанного с ней законодательства.

С началом советского периода интерес к истории отечественной пенитенциарной системы существенно возрос, что было вызвано, с одной стороны, стремлением пришедших к власти сил зафиксировать следы преступлений свергнутого ими режима, а с другой - потребностью популяризации революционного движения и его выдающихся деятелей. При этом наиболее характерной чертой исследований в изучаемой сфере являлась их идеологическая направленность. В довоенных работах С.К. Сизова (Сизов, 1928), С.А. Кудрявцева (Кудрявцев, 1936), Н.М. Гернета (Гернет, 1930) и других режим отбывания наказания в царских тюрьмах однозначно оценивался как бесчеловечный и преступный, героизировалась борьба его узников за свои права и революционные идеалы. В доперестроечный период внимание советских авторов по проблемам отбывания наказания 
в царской России было акцентировано в основном на положении политических заключенных. Проведенные в этой связи исследования, в том числе диссертационные, И.А. Сенченко (Сенченко, 1963), Э.Ш. Хазиахметова (Хазиахметов, 1978), Р.С. Мулукаева (Мулукаев, 1964), Н.И. Биюшкина (Биюшкин, 1964), В.Г. Смольякова (Смольяков, 1979) и других посвящались главным образом истории политической каторги и ссылки. Крупнейшим трудом данного периода по проблемам организации и деятельности мест заключения Российской империи следует признать неоднократно переиздававшееся в 50-6о-е гг. исследование «История царской тюрьмы» М.Н. Гернета (Гернет, 1961), в котором наиболее полно и систематизированно нашли свое отражение важнейшие аспекты правового положения заключенных российских тюрем.

Новейший период применительно к исследованиям организационных и правовых основ российских пенитенциарных учреждений, правового положения их контингента характеризуется отказом от идеологической составляющей. Работы М.Г. Деткова (Детков, 1994), И.П. Упорова (Упоров, 2004), Л.П. Рассказова (Рассказов, 1999), Л.Ф. Пертли (Пертли, 2011), В.И. Алексеева (Алексеев, 2004), А.Ю. Сибилевой (Сибилева, 2018) (сноски) и других раскрыли многие важные аспекты отбывания наказания в дореволюционных местах заключения, в том числе региональных.

Что касается Саратовской губернии, то, несмотря на ее важнейшее социально-экономическое значение для России, а также развитую пенитенциарную систему, необходимо признать, что научные исследования по затрагиваемой проблематике в основном обошли ее стороной. Упоминания достойно лишь библиографическое исследование изданий о дореволюционных местах заключения Саратова, принадлежащее перу В.А. Сушицкого (Сушицкий, 1933).

В целом, применительно к теме настоящей статьи следует признать, что упомянутые исследования не являются комплексными и носят фрагментарный характер.

\section{4. Результаты}

Развитие системы пенитенциарных учреждений в Российской империи, начиная со второй половины XIX века, непосредственно связано как с общественно-экономической трансформацией, освободившей значительное количество населения не только от крепостной зависимости, но и от механизмов социального регулирования, присущих крестьянской общине, так и с ростом революционного движения в России. Насущные потребности государственной карательной политики вызвали не только ужесточение, но и дифференциацию условий содержания определенных разрядов заключенных, учитывая степень их общественной опасности. Совершенно особую категорию при этом составили государственные преступники, представлявшие угрозу для государственного строя и подлежавшие строгой изоляции как от внешнего мира, так и от прочих заключенных.

Установленные тюремной администрацией быт заключенных, прежде всего относящихся к числу политических противников царского режима, система надзора за ними, условия их содержания и обращения с ними на практике представляли собой средство их физического подавления, зачастую приводя их к непоправимому подрыву здоровья и мучительной гибели в застенках. Со временем, по мере развития культуры прав человека и общественно-политической ситуации в стране, обстановка в пенитенциарной системе стала постепенно меняться.

Несмотря на то, что правовая система Российской империи не ставила во главу угла правовой статус личности и не рассматривала ее как обладающую неотъемлемыми правами, которые должны гарантироваться при любых обстоятельствах, проблемы прав человека (в терминологии того времени - «гражданских свобод», «либерализма» и т.п.) были предметом обсуждения и осмысления в образованных слоях российского общества на протяжении всего XIX века. Особую значимость приобрел тогда опыт Великой французской революции: зарубежные исследования по ее истории вначале становились известными в нашей стране на языке оригинала, однако впоследствии были опубликованы и их переводы на русский язык, а через некоторое время появились и работы российских авторов. Значительный вклад в популяризацию подхода, основанного на правах человека, внесла длительная публичная дискуссия «славянофилов» и «западников», а также неподцензурная русскоязычная литература, издававшаяся в эмиграции. В то же время вопросы тюремной реформы рассматривались не с позиций необходимости обеспечения прав и свобод человека, а с позиций христианского гуманизма и, выражаясь словами А.С. Пушкина, «милости к падшим» (Пушкин, 1841: 121). Основной задачей пенитенциарной системы провозглашалось «исправление» осужденных, их последующее возвращение к обычной жизни, что часто оказывалось несовместимым с реальными условиями их содержания.

Стремительный рост политической и общеуголовной преступности, усиливавшееся сопротивление своей участи контингента российских тюрем настоятельно требовали перемен как в стратегии, так и в тактике проведения карательной политики посредством мест заключения. Одним из характерных признаков таких перемен стали регламентация и обеспечение на практике прав заключенных, направленные прежде всего на создание приемлемых условий отбывания наказания. Общая тюремная инструкция закрепляла соответствующие положения и настоятельно предписывала надзорсоставу человеколюбивое, спокойное и справедливое обхождение с заключенными. Употребление в их адрес ругани и оскорблений при этом катогорически запрещалось (Общая..., 1916: 87). 
В рамках данного исследования особое внимание уделено основам гуманного обращения и обеспечению в тюрьмах Российской империи на рубеже XIX-XX вв. таких прав заключенных, как право на охрану здоровья и право на труд и его оплату при привлечении арестантов к работам.

Сущность тюремной реформы конца XIX в. сводилась к учреждению центрального государственного органа по управлению всеми тюремными учреждениями империи со специализацией его подразделений в административном и хозяйственном отношении, а также унификации тюремного дела на местах. С учреждением в 1879 г. в структуре МВД Главного тюремного управления местные тюремные органы получили в его лице более эффективную исполнительную и распорядительную инстанцию, способную объединить и возглавить решение стоящих перед ведомством задач. Вместе с тем необходимо отметить, что за недостатком средств (необходимых для тюремной модернизации 42 млн руб. в государственной казне не было) царское правительство вынуждено было проводить намеченные преобразования постепенно. В целом, сама идея всеобщей тюремной реформы властями была отвергнута и была подменена тактикой усовершенствования отдельных, самых уязвимых звеньев пенитенциарной системы, в том числе в изучаемой сфере (Мулукаев и др., 2005: 72).

На губернском и областном уровнях управление пенитенциарными учреждениями в результате названной реформы было сосредоточено у губернаторов, начальников областей и градоначальников, а также полиции (Свод..., 1890: 21). Именно к их компетенции были отнесены контроль за исполнением правительственных постановлений, регулирующих режим содержания заключенных, а также надзор за благоустройством тюрем. Поначалу, однако, администрация губерний самоустранилась от разрешения насущных проблем в сфере отбывания наказания, избегая даже таких проявлений своей власти, как ревизии и контроль.

21 марта 1890 г. с санкции императора в России была учреждена губернская тюремная инспекция (Собрание, 1890: 407). К началу 1913 г., согласно Закону от 31 марта 1890 г., на местах были назначены 35 губернских тюремных инспекторов (еще 21 чиновник исполнял эту должность), которым было поручено заведование тюремной частью на вверенной территории (Органы..., 1996: 133). Все они находились в непосредственном подчинении Главного тюремного управления. Согласно ст. 24 Устава о содержании под стражей, в рамках своих «ближайших обязанностей» губернский тюремный инспектор надзирал за порядком исполнения законодательных норм о порядке содержания заключенных, а также следил за благоустройством пенитенциарных учреждений. В рамках своих полномочий губернские тюремные инспекторы наделялись дисциплинарной властью, необходимой им для наведения должного порядка, правом беспрепятственного доступа во все помещения тюрем, личного общения с их заключенными, а также ознакомления с соответствующей документацией. Тюремные инспекторы проводили ревизии как тюремного хозяйства соответствующих пенитенциарных учреждений, так и порядка содержания арестантов, их бытовых условий.

30 мая 1890 г. министром внутренних дел было внесено предложение № 7887 о введении с 1 июля того же года положения о губернской тюремной инспекции в Саратовской губернии. Руководствуясь названными нормативными актами, Саратовское губернское правление образовало в своем составе особое тюремное отделение. Данное учреждение, состоящее в ведении губернского тюремного инспектора под непосредственным руководством губернатора, осуществляло функции, связанные с управлением и надзором в местах лишения свободы (касающиеся порядка прохождения службы их личным составом); порядка содержания арестантов в местах заключения; порядка производства арестованными работ; обеспечения ссыльных и арестантов необходимым обмундированием и средствами жизнеобеспечения; ведения связанной с тюремными делами финансово-хозяйственной деятельности (ГАВО. Ф. 290. Оп. 1. Д. 4. Л. 59-60).

К началу 1902 г. контингент пенитенциарных учреждений Российской империи составлял 88851 человек (Отчет, 1904: 12-13). Саратовская губерния насчитывала 1843 арестанта и была оснащена центральной губернской тюрьмой (434 заключенных), исправительным арестантским отделением в губернском центре (528), а также Хвалынской (52), Камышинской (110), Балашовской (74), Аткарской (102), Петровской (72), Царицынской (237), Вольской (81), Кузнецкой (90) и Сердобской (63) уездными тюрьмами (ГАСО. Ф. 655. Оп. 1. Д. 396. Л. 34). Как и в некоторых других крупных российских городах, в начале $\mathrm{XX}$ в. для размещения осужденных каторжников в Саратове была создана специальная временная тюрьма.

Традиционно российские заключенные в тюрьмах содержались в условиях чрезвычайной скученности, преодолеть которые до конца оказалось невозможным. Порой переполнение достигало таких масштабов, что лишало администрацию тюрем всякой возможности обеспечить удовлетворительное содержание арестантов хоть в какой-то мере. Согласно официальному отчету Главного тюремного управления, на 1 января 1882 г. общее количество заключенных превышало число имевшихся тюремных мест на 24 \%. В зависимости от социально-экономических условий в регионах, а также уровня преступности в них переполнение тюрем могло иметь различные показатели, порой лишая тюремную администрацию всякой возможности обеспечить хоть в какой-то мере удовлетворительный порядок содержания арестантов. Так, среди наиболее неблагополучных в данном отношении губерний можно назвать следующие: в Петраковской губернии на одно тюремное 
место приходилось 5,2 заключенных; Сувалкской - 2,7; Седлецкой и Оренбургской - 2,6; Саратовской - 2,5; Симбирской - 2,3 (Органы, 1996: 123).

К числу требующих незамедлительного разрешения проблем как в центре, так и на местах, относилось крайне неудовлетворительное состояние тюремных зданий и сооружений, а также недопустимые условия содержания заключенных. Порой дело в них доходило до полного отсутствия даже элементарных условий, пригодных как для человеческого существования, так и изоляции арестантов. Необходимые для проведения работ по реконструкции, расширению и совершенствованию тюремных помещений средства повсеместно отсутствовали. В свою очередь названные обстоятельства создавали реальные причины и условия для возникновения массовых беспорядков в местах заключения, а также побегов арестантов. Несмотря на это, МВД, а затем и Министерство юстиции проводили режим жесткой экономии бюджетных расходов по тюремной части, отпускаемых на пропитание и обмундирование заключенных (Органы, 1996: 124).

К числу самых насущных проблем российских пенитенциарных учреждений изучаемого периода относилось обеспечение права арестантов на охрану здоровья. Данная проблема заслуживает отдельного рассмотрения, что и будет сделано нами детально в последующем. Вместе с тем отметим, что как Главным тюремным управлением, так и администрацией пенитенциарных учреждений на местах, невзирая на дефицит необходимых помещений, оборудования и средств, предпринимались настойчивые меры по обеспечению лечения арекстантов, противодействию эпидемиологическим заболеваниям, а также медико-санитарной профилактике. Ообое внимание при этом Главным тюремным управлением уделялось профилактике туберкулеза (ГАВО. Ф. 161. Оп. 1. Д. 14. Л. 27). В аналогичном порядке осуществлялась борьба с тифом (ГАВО. Ф. 161. Оп. 1. Д. 14. Л. 38). Саратовскому губернатору, наряду с прочими, было предложено принять меры по поддержанию в местах заключения вверенной губернии надлежащих санитарных и гигиенических условий (ГАВО. Ф. 290. Оп. 1. Д. 34. Л. 15).

Важнейшим элементом тюремной реформы было признано трудовое использование заключенных. Стремясь придать ему организованный характер, Главное тюремное управление установило для ряда их категорий обязательное привлечение к работам; для того чтобы материально заинтересовать трудящихся арестантов, регламентировало порядок начисления им заработной платы. Вместе с тем, учитывая реальные сложности с обеспечением трудового использования арестантов на практике, все директивные указания, адресованные тюремной администрации на местах по этому поводу, носили рекомендательный характер, а само их привлечение к труду осуществлялось в добровольном порядке, что позволяет отнести данную меру именно к числу мер, направленных на обеспечение трудовых прав заключенных.

Попечение о занятии содержащихся в местах заключения арестантов работами и непосредственное заведование последними было отнесено к компетенции руководства мест заключения (Свод..., 1890: 344-345). Размещение заказов для тюремных мастерских, а также обеспечение права заключенных на труд в целом было поручено комитетам и отделениям Попечительного о тюрьмах обшества. Названные комитеты и отделения, усмотрев отклонения от установленного законом порядка в данной сфере, обязаны были всякий раз обращать внимание соответствующего начальника (смотрителя) тюрьмы на допущенные «неправильности». На тот случай, если это не вызывало искомого эффекта, предусматривалось обращение по этому вопросу непосредственно к губернатору. Заботясь о постоянном занятии арестантов работами, а также предоставляя им возможность заработать при этом как можно больше, Министерство юстиции по возможности имело право привлекать их к работам при казенных общественных зданиях на условиях вольнонаемного труда.

Наряду с добровольным использованием труда арестантов в пенитенциарных учреждениях, в ряде случаев предусматривалось обязательное привлечение к работам их некоторых категорий, в частности каторжников, заключенных исправительных арестантских отделений, воров, мошенников, растратчиков, а также попрошаек (Свод..., 1890: 345). По распоряжению тюремного начальства арестанты могли быть освобождены от работ по болезни, учитывая соответствующее заключение врача. В случае же стойкой нетрудоспособности Уставом о содержащихся под стражей предусматривалось полное освобождение от работ (Свод..., 1890: 347). При поступлении в тюрьмы женщин, имеющих грудных младенцев, тюремная администрация была обязана строжайшим образом следить за тем, чтобы осужденные этой категории не привлекалась к работам, препятствующим исполнению ими своих материнских обязанностей (Свод..., 1890: 348 ).

Арестанты, не подлежащие обязательным работам, могли работать по желанию, но при условии соблюдения внутреннего и трудового распорядка. Суточная продолжительность работ, согласно установленному распорядку, не превышала 11 часов летом и 10 часов зимой, включая занятия арестантов в школе и прием ими пищи. Уставом о содержащихся под стражей предусматривалось освобождение арестантов всех категорий от работ в праздничные дни (Свод..., 1890: 352).

Практика показала, что тюремная администрация отнеслась к трудовому использованию вверенных им арестантов без особого энтузиазма, вследствие чего их заработок постоянно снижался. Так, например, по наблюдениям саратовского тюремного инспектора, вследствие бездеятельности 
«подлежащих начальников» по поиску заказов на труд заключенных и сбыта арестантских изделий в 1904 г. (по сравнению с 1903 г.) их усилия успеха не имели. В результате подобного отношения в Вольской тюрьме общий заработок заключенных снизился соответственно с 511 руб. 55 коп. до 138 руб. 50 коп.; в Камышинской тюрьме - с 542 руб. 15 коп. до 48 руб. 45 коп. В этой связи названным тюремным инспектором руководству региональных пенитенциарных учреждений было отдано циркулярное распоряжение «озаботиться занятием работами» всех вверенных трудоспособных заключенных. Признавая труд вообще одним из наиболее действенных средств исправления арестантов, он рекомендовал обратить особое внимание на развитие в тюрьмах простейших внутренних производств. Получившие прежде широкое распространение в Саратовской губернии внутренние работы при этом признавались наиболее соответствующими тюремному режиму, способными предоставить каждому заключенному по отбытии наказания за короткий срок своим трудом заработать средства «на кусок хлеба». С учетом имеющегося положительного опыта приветствовалось выделение средств из заработного фонда на приобретение инструментов, оптовую заготовку материалов и наем мастеров (ГАВО. Ф. 290. Оп. 1. Д. 26. Л. 69).

Условиям арестантского труда как внутри тюремных помещений, так и за их пределами был посвящен целый ряд циркуляров Главного тюремного управления 80-х гг. ХIX в., которые внутри помещений рекомендовали организовывать среди арестантов изготовление ширпотреба (не требующего каких-либо навыков или профессиональной квалификации) из местных материалов, дающее достаточный заработок для приемлемого существования после освобождения из заключения. Квалифицированный труд заключенных, требующий применения сложного оборудования и приспособлений, Главним тюремным управлением стал практиковаться лишь с 1902 г., когда в его составе было образовано отделение по организации труда осужденных (Гернет, 1961: 16).

Со временем заинтересованность тюремной администрации в результатах трудоиспользования арестантов, особенно квалифицированных мастеров, возрастала. Порой дело доходило до того, что это оказывало самое пагубное влияние на переполненность мест заключения контингентом. Согласно ст. 284-286 Устава о содержании под стражей, все трудоспособные лица, осужденные на отдачу в исправительные арестантские отделения, в обязательном порядке для отбытия наказания направлялись туда. Лишь в порядке исключения, за неимением в названных отделениях мест либо их отдаленности, осужденных допускалось оставлять в тюрьмах, привлекая их при этом к самым тяжелым из установленных там работ. Согласно особым правилам, распространенным на места при циркуляре от 15 ноября 1893 г. № 18, местному тюремному начальству было предоставлено право задерживать в своем распоряжении тех арестантов, оставление которых было продиктовано производственной необходимостью. Именно этим обстоятельством обяснялось оставление большинства заключенных данной категории в и без того переполненных и недостаточно обеспеченных надзором губернских и уездных тюрьмах. Лишь 1 декабря 1904 г. задержка арестантов в тюрымах под предлогом производства работ Главным тюремным управлением была окончательно запрещена (ГАВО. Ф. 290. Оп. 1. Д. 26. Л. 98).

Уставом о содержащихся под стражей допускалось использование труда арестантов как в пределах тюремной ограды, так и вне ее. При этом Главное тюремное управление непосредственно определяло характер работ, к производству которых арестанты могли привлекаться как в обязательном порядке, так и по собственному желанию (Свод..., 1890: Ст. 253-254). Исправительные арестантские отделения в обязательном порядке снабжались необходимыми инструментами и орудиями труда. Начальники, имеющие в своем ведении арестантов, привлекать их для работы в свою пользу права не имели. На работы за пределами тюремной ограды запрещалось назначать ряд категорий арестантов, в том числе женщин, лишенных всех прав состояния и бродяг.

Необходимо отметить, что обеспечение администрацией российских пенитенциарных учреждений права арестантов на труд не подразумевало мер по его охране и созданию для него соответствующих условий (Свод..., 1890: 355-357). Все без исключения привлеченные к работе арестанты имели право на не облагаемое никакими взысканиями денежное вознаграждение, а также его расходование в установленных размерах (Свод..., 1890: 358, 365, 368). Заработок умершего в местах заключения арестанта выдавался его наследникам.

Согласно ст. 16 и 64 Устава о содержащихся под стражей заботиться об улучшении как нравственного, так и физического состояния заключенных российских тюрем было призвано пользующееся особым покровительством императора и состоящее при Министерстве юстиции Попечительное о тюрьмах общество (Свод..., 1890: 67, 98). В рамках своих полномочий оно призвано было обеспечивать надлежащие для здоровья арестантов условия отбывания наказания; их правильное размещение с учетом пола, звания, возраста и характера преступлений; снабжение их в достаточной мере продовольствием; исправное состояние мест заключения; надлежащее лечение больных заключенных; обеспечение их обмундированием и необходимыми принадлежностями; «исправление нравственности» осужденных; строительство и содержание «в должном благолепии» тюремных церквей; оперативное разрешение участи заключенных, а также иных вопросов, связанных с обеспечением их прав. На предмет этого тюремные комитеты названного общества наблюдали за чинами надзорсостава, с тем чтобы те неукоснительно соблюдали установленные правила отбывания 
наказания арестантами и «благочиние» между ними. Заботясь совместно с начальством мест лишения свободы об участи заключенных, согласно ст. 91 Устава о содержании под стражей, они призваны были содействовать нравственному исправлению заключенных и всячески препятствовать их ожесточению (Свод..., 1890: 91-92). Вице-президенты губернских тюремных комитетов и старшие директора уездных тюремных отделений в пределах своей компетенции наделялись правом давать предписания чинам тюремной администрации и надзорсостава. С целью прекращения «беспорядков» с их стороны, а также ненадлежащего исполнения ими своих служебных обязанностей первые лица тюремных комитетов были вправе информировать об этом непосредственно губернатора (Свод..., 1890: 98).

Между тем как должностное, так и социальное положение членов региональных тюремных комитетов оставляли для них мало возможностей для создания приемлемых условий отбывания наказаний, связанных с лишением свободы. Саратовский губернского общества попечительного о тюрьмах комитет квалифицировал себя в качестве учреждения, преследующего высоконравственные и благотворительные цели в интересах заключенных, постоянно нуждающихся в «живом и теплом участии» его членов, добровольно и бескорыстно принявших на себя обязанности попечения и надзора за ними. Наряду с этим, «весьма желательным и существенно необходимым» признавалось то, чтобы директора названного комитета не ограничивались одним только внешним наблюдением за вверенными им пенитенциарными учреждениями, а приняли бы на себя деятельное участие в заведовании хозяйственной частью местной тюрьмы.

28 декабря 1888 г. в составе комитета была образована постоянная комиссия, наблюдавшая за хозяйственными делами саратовской тюрьмы. Полномочия контроля и надзора по отдельным направлениям деятельности комиссии были распределены между губернским архитектором, губернским врачебным инспектором, прокурором окружного суда, двумя советниками губернского правления, губернским воинским начальником, мировым судьей, армейским поручиком запаса, потомственным почетным гражданином, действительным статским советником и двумя купцами (ГАВО. Ф. 290. Оп. 1. Д. 4. Л. 12-14).

Регламентация Устава о содержащихся под стражей прав арестантов включала ряд непреложных правил относительно порядка отбывания ими наказания. Так, содержащиеся под стражей по всем уголовным делам в обязательном порядке разделялись по половому признаку (Свод..., 1890: 172). Существенное значение для обеспечения прав осужденных женщин, равно как и для облегчения их участи в целом, имело введение законом от 13 июня 1887 г. в состав стражи тюремных надзирательниц, призванных осуществлять надзор за находящимися в заключении лицами женского пола.

Малолетние и несовершеннолетние подлежали отдельному содержанию от прочих заключенных (Свод..., 1890: 173). Сословными привилегиями при отбывании заключения пользовались дворяне, чиновники, также разночинцы и иностранцы, которых полагалось размещать отдельно от крестьян и мещан (Свод..., 1890: 174). Однако на практике раздельное содержание привилегированного и общеарестантского контингента зачастую оказывалось затруднительным ввиду хронического недостатка соответствующих помещений. Отдельному содержанию подлежали также арестанты, находящиеся под следствием и судом, политические, «важные» преступники, а также «неисправные должники» (Свод..., 1890: 175-177). Кроме того, на период содержания в тюрымах от иных заключенных изолировались лица женского пола, осужденные на кратковременное заключение в монастыре (Свод..., 1890: 178).

«Правилами содержания политических арестантов в губернских и уездных замках и пересыльных тюрымах» от 28 февраля 1886 г. был регламентирован режим содержания политических заключенных как самостоятельной категории осужденных. 16 апреля 1904 г. министр юстиции выпустил в свет новые правила, регулирующие порядок содержания в тюрьмах гражданского ведомства политических арестантов. Фактически они приравнивали режим отбывания наказания политическими заключенными к уголовному. Вместе с тем им была предоставлена возможность заниматься умственным и физическим трудом. Политзаключенным из непривилегированных сословий запрещалось питаться за свой счет, участвовать в хозработах, избирать из своей среды старост, устраивать кассы взаимопомощи. Курить разрешалось начальником места заключения только с санкции губернатора. Подобного снисхождения согласно ст. 25 названных правил удостаивались лишь те политические арестанты, на состоянии здоровья которых по заключению тюремного врача должно было вредно отразиться прекращение курения (Правила..., 1904: 10).

Согласно Правилам отбывания тюремного заключения политическими арестантами от 16 ноября 1906 г., осужденные этой категории выделялись тюремным ведомством в особый разряд лишь на период состояния под следствием или судом. По вступлении же приговора в силу, все заключенные признавались отбывающими наказание одинаково. Различия наступали лишь с учетом действующего тюремного режима или применяемого вида лишения свободы.

В тех случаях, когда, наряду с государственными, заключенным вменялись общеуголовные преступления (убийство, разбой, грабеж, бродяжничество и т.п.), к ним применялись лишь те положения названных правил, которые касались политзаключенных. Предусмотренные для них особые меры предосторожности включали регулярное производство обысков, изоляцию от других 
категорий заключенных, разрешение свиданий исключительно с близкими родственниками, запрещение передач в виде готовых продуктов питания. Вместе с тем арестанты, осужденные за уголовные преступления, не вправе были требовать особой пищи, предусмотренной для чисто государственных преступников, равно как и иных, предусмотренных исключительно для них льгот (ГАВО. Ф. 290. ОП. 1. Д. 43. Л. 5).

Следственные арестанты имели право на одиночное размещение в отдельных камерах тюрем и арестантских помещений. Даже при невозможности устройства таковых в пенитенциарных учреждениях с этой целью нанимались частные дома с надлежащим оборудованием (Свод..., 1890: 181).

Арестанты, содержащиеся в тюрьмах гражданского ведомства, имели право на снабжение казенным обмундированием. Имевшиеся на этот счет некоторые исключения в 1887 г. Главным тюремным управлением были устранены из опасения побегов (Свод..., 1890: 191, 193). С этого времени всем без исключения заключенным, содержащимся в тюрымах, полагалось выдавать казенные постельные принадлежности (Свод..., 1890: 192). Каждая из российских тюрем в обязательном порядке располагала полным комплектом арестантского обмундирования и постельных принадлежностей, рассчитанным по специальным нормативам. В особом порядке осуществлялось снабжение обмундированием арестантов из числа военнослужащих и казаков. С 1887 г. обеспечение права заключенных на надлежащее снабжение одеждой, обувью, бельем и постельными принадлежностями, их исправное состояние и починку было включено в число непосредственных обязанностей начальника тюрьмы (Свод..., 1890: 199).

Все арестанты, какого бы рода и состояния они ни были, без различия военного и гражданского ведомств имели право на питание за счет казны (Свод..., 1890: 205). В каждой губернии и области Российской империи по ежегодно составляемому в губернском или областном правлении и утверждаемому непосредственно губернатором табелю на пропитание арестантов отпускались особые средства. При этом их паек включал обязательный ассортимент продуктов, отпускаемых ежегодно по максимальным рыночным ценам. В случае, если по какой-то причине их оказывалось недостаточно, в указанном порядке принималось решение о необходимой прибавке к определенным по табели «кормовым деньгам». Заключенные, принадлежащие к высшим сословиям, могли рассчитывать на льготные условия продовольственного обеспечения, но при условии, если они не имели собственных средств к своему содержанию (Свод..., 1890: 207). В особом порядке обеспечивались продовольствием заключенные военнослужащие и казаки. С 1887 г. осужденные на тюремное заключение приобрели право с разрешения местного Попечительного о тюрьмах комитета либо местного начальства питаться самостоятельно, за счет собственных средств, не допуская, однако, при этом никаких излишеств (Свод..., 1890: 267).

Значительными преимуществами по сравнению с прочими заключенными в пенитенциарных учреждениях обладали несовершеннолетние, беременные и кормящие матери. Так, находящимся в местах заключения малолетним детям кормовые деньги выдавались наравне со взрослыми арестантами (Свод..., 1890: 209). Тюремные комитеты особо наблюдали за тем, чтобы содержащимся в тюрьмах беременным и особенно имеющим грудных младенцев женщинам пища выдавалась лучшего качества, нежели другим заключенным (Свод..., 1890: 213). Между тем в период Первой мировой войны и без того скудное снабжение арестантов продовольствием ослабело еще больше. 4 июня 1916 г. Главным тюремным управлением впервые была признана недостаточность питания заключенных (Тюремный вестник, 1916: 574).

Просить милостыню арестантам категорически запрещалось, причем ведающее их конвоированием военное начальство обязано было строго следить за тем, чтобы за пределами тюрем заключенные ни в коем случае не просили подаяния у окрестного населения. Вместе с тем при тюрьмах, в церквях, на торговых площадях, рынках, базарах и иных местах для сбора добровольных подаяний в пользу арестантов выставлялись опечатанные тюремными комитетами особые кружки. Кроме того, членами и благотворителями Общества попечительного о тюрьмах практиковались ежегодные и единовременные пожертвования на эти же цели (Свод..., 1890: 219-222).

Таким образом, тюремная реформа конца XIX - начала XX вв. способствовала не только централизации управления и унификации тюремного дела на местах, но и отражала распространяемые в обществе того периода демократические и гуманистические идеи о правах человека и достоинстве личности, что способствовало изменению отношения к заключенному и карательным мерам, которым он должен подвергаться в период отбывания наказания. Вместе с тем проблема формирования культуры прав человека, в том числе прав заключенного, требует комплексного анализа. За рамками настоящей статьи остались проблемы обеспечения целого ряда прав и свобод арестантов, которые гарантировались в данный исторический период, в частности свобода совести, право на связь с внешним миром, свобода от жестокого обращения и многие другие. Они станут предметом исследования в последующих работах авторов статьи.

\section{5. Заключение}

Российское общество на рубеже XIX-XX вв. характеризуется значительным интересом к проблемам обеспечения достоинства личности. Происходившая в тот период модернизация 
российской экономики, давшая значительный импульс развитию юриспруденции, усилила акцент на необходимости правового закрепления новых представлений о человеке, его правах и свободах, в том числе применительно к системе исполнения наказаний. Вместе с тем этот процесс сталкивался с препятствиями как объективного, так и субъективного характера, в том числе с ограниченностью ресурсов государства в целом и его пенитенциарной системы в частности. Кроме того, в указанный период не удалось системно решить проблему эффективного использования труда заключенных в условиях рыночной экономики. В целом процессы формулирования представлений о правовом статусе личности в Российской империи конца XIX-начала XX вв. следует считать прогрессивными, так как они стали важным этапом становления культуры прав человека в России. Документы Государственного архива Саратовской области и Государственного архива Волгоградской области, впервые введенные в научный оборот в настоящем исследовании, служат значимым подтверждением данного вывода. Отличающимся существенной новизной, по мнению авторов, является комплексное раскрытие аспектов, связанных с организацией и деятельностью пенитенциарных учреждений такого значимого региона Российской империи, как Саратовская губерния, равно как и освещение проблем обеспечения прав заключенных российской тюремной системы в целом.

\section{Литература}

Алексеев, 2014 - Алексеев В.И. Тюремная реформа в России 1879 года. М., 2004. 554 с.

Биюшкина, 2011 - Биюшкина Н.И. Правовое регулирование условий содержания политических преступников в Российской империи в период правления Александра III // Вестник Владимирского юридического института. 2011. № 2. С. 140-146.

ГАВО - Государственный архив Волгоградской области.

ГАСО - Государственный архив Саратовской области.

Гернет, 1930 - Гернет М.Н. В тюрьме. Очерки тюремной психологии. 2-е издание, дополненное новыми очерками и иллюстрациями. Харьков, 1930. 263 с.

Гернет, 1961 - Гернет М.Н. История царской тюрьмы. Т. 3. М., 1961. 430 с.

Гогель, 1897 - Гогель С.К. Арестантский труд в русских и иностранных тюрьмах. М., 1897. 134 с.

Детков, 1994 - Детков М.Г. Наказание в царской России. Система его исполнения. М., 1994. 119 с.

Красовский, 1900 - Красовский М.И. Вопросы устройства русских исправительных заведений для несовершеннолетних. С приложением узаконений и распоряжений правительства, относящихся к малолетним и несовершеннолетним преступникам. Саратов, 1900. $219 \mathrm{c.}$

Кудрявцев, 1936 - Кудрявцев Ф.А. Александровский централ: из истории сибирской каторги. Иркутск, 1936. 97 с.

Линев, 1880 - Линев Д.А. В пересыльной тюрьме. СПб., 1880. 350 с.

Мулукаев и др., 2005 - Мулукаев Р.С., Мальгин А.Я., Епифанов А.Е. История отечественных органов внутренних дел. Учебник для вузов. М., 2005. 335 с.

Мулукаев, 1964 - Мулукаев Р.С. Полиция и тюремные учреждения дореволюционной России. M., 1964. 28 c.

Никитин, 1880 - Никитин В.Н. Тюрьма и ссылка. Историческое, законодательное, административное и бытовое положение заключенных, пересыльных, их детей и освобожденных изпод стражи со времени возникновения русской тюрымы до наших дней. 1560-1880. СПб., 1880.674 с.

Николаевский, 1898 - Николаевский Н. Тюрьма и ссылка. Очерки политической и религиозной ссылки. М., 1898. 201 с.

Общая..., 1915 - Общая тюремная инструкция. Утверждена Министром юстиции 28 декабря 1915 г. Пг, 1916. $110 \mathrm{c.}$

Органы..., 1996 - Органы и войска МВД России. Краткий исторический очерк. М., 1996. 463 с.

Отчет, 1904 - Отчет по Главному тюремному управлению за 1902 год. СПб., 1904. 397 с.

Пертли, 2011 - Пертли Л.Ф. Организационно-правовые основы условий содержания заключенных в дореволюционной России / Под науч. ред. С.И. Кузьмина. М., 2011. 200 с.

Познышев, 1915 - Познышев С.В. Очерки тюрьмоведения. М., 1915. 295 с.

Правила..., 1904 - Правила о содержании в тюрьмах гражданского ведомства политических арестантов. СПб., 1904. 13 с.

Пушкин, 1841 - Пушкин А.С. Сочинения. В 11 т. Т. 9. СПб., 1841. С. 121.

Рассказов, Упоров, 1999 - Рассказов Л.П., Упоров И.Я. Тюремные инструкции в Российской империи. Краснодар, 1999. 57 с.

Сборник..., 1911 - Сборник циркуляров, изданных по Главному тюремному управлению в 18791910 гг. Ч. 1. СПб., 1911. 461 с.

Свод..., 1890 - Свод законов Российской империи. Том четырнадцатый. Уставы о паспортах, о предупреждении преступлений, о цензуре, о содержащихся под стражей и о ссыльных. СПб., 1890. $909 \mathrm{c}$.

Сенченко, 1963 - Сенченко И.А. Революционеры России на Сахалинской каторге. ЮжноСахалинск, 1963. $191 \mathrm{c.}$ 
Сибилева, 2018 - Сибилева А.Ю. Правовые основы деятельности тюрем в Таврической губернии (конец XVIII - начало XX вв.). Симферополь, 2018. 251 с.

Сизов, 1928 - Сизов С.К. Дореволюционная тюрьма и советский исправительно-трудовой дом. Армавир, 1928. 22 с.

Смольяков, 1979 -- Смольяков В.Г. Тюремная система дореволюционной России, ее реакционная сущность. М., 1979. 23 с.

Собрание..., 1890 - Собрание узаконений и распоряжений правительства № 49 от 22 мая 1890 г. СПб., 1890. $94 \mathrm{c.}$

Сушицкий, 1933 - Сушицкий В. Саратовские тюрымы // Известия Саратовского НижнВолжского института краеведения. 1933. 3 апр. С. 157-197.

Таганцев, 1902 - Таганцев Н.С. Русское уголовное право. Часть общая: лекции Н.С. Таганцева. 2-е издание, пересмотренное и дополненое. СПб., 1902. 256 с.

Тюремный вестник, 1910 - Тюремный вестник. 1910. № 3.193 с.

Тюремный вестник, 1916 - Тюремный вестник. 1916. № 6-7. 168 с.

Фойницкий, 1884 - Фойницкий И.Я. Курс русского уголовного судопроизводства, составленный по лекциям профессора С.-П. Бургского университета И.Я. Фойницкого и изданный в руководство слушателям 1883-1884 года. Т. 2. СПб., 1884. 664 с.

Хазиахметов, 1978 -- Хазиахметов Э.Ш. Сибирская политическая ссылка 1905-1917 гг.: Облик, организация, революционные связи. Томск, 1978. 183 с.

Ядринцев, 1872 - Ядринцев Н.М. Русская община в тюрьме и ссылке. СПб., 1872. 719 с.

\section{References}

Alekseev, 2004 - Alekseev, V.I. (2004). Tyremnaya reforma v Rossii 1879 goda [Prison reform in Russia in 1879]. M. 554 p. [in Russian]

Biyushkina, 2011 - Biyushkina, N.I. (2011). Pravovoe regulirovanie usloviy sodergania politicheskih prestupnikov v Rossiyskoy imperii v period pravleniya Aleksandra III [Legal regulation of the conditions of detention of political criminals in the Russian Empire during the reign of Alexander III]. Vestnic Vladimirskogo yridicheskogo instituta. 2: 140-146. [in Russian]

GAVO - Gosudarstvennyy arkhiv Volgogradskoy oblasti [State Archives of the Volgograd Region].

GAVO - Gosudarstvennyy arkhiv Saratovskoy oblasti [State Archives of the Saratov Region].

Gernet, 1930 - Gernet, M.N. (1930). V tyr'me. Ocherki tyremnoy psihologii. 2-e izdanie, dopolnennoe novymi ocherkami I illustraciyami [In prison. Essays on Prison Psychology. 2nd edition, updated with new sketches and illustrations]. Char'kov. 263 p. [in Russian]

Gernet, 1961 - Gernet, M.N. (1961). Istoriya carskoj tyur'my [The history of the tsarist prison]. T. 3. M. 430 p. [in Russian]

Gogel', 1897 - Gogel', S.K. (1897). Arestantskiy trud v russkih I inostrannyh tyr'mah [Prison labor in Russian and foreign prisons]. M. 134 p. [in Russian]

Detkov, 1994 - Detkov, M.G. (1994). Nakazanie v Carskoy Rossii. Sistema ego ispolneniya [Punishment in Tsarist Russia. The system of its execution]. M. 119 p. [in Russian]

Krasovskiy, 1900 - Krasovskiy, M.I. (1900). Voprosy ustroystva russkih ispravitel'nyh zavedeniy dlya nesovershennoletnih. S prilozheniem uzakoneniy I rasporyazheniy pravitel'stva, otnosyashihsya $k$ maloletnim i nesovershennoletnim prestupnikam [Questions of the device of Russian correctional institutions for minors. With the attachment of legalizations and government orders relating to juvenile and juvenile offenders]. Saratov. 219 p. [in Russian]

Kudryavcev, 1936 - Kudryavcev, F.A. (1936). Aleksandrovskiy cental: iz istorii sibirskoy katorgi [Alexandrovsky Central: from the history of Siberian penal servitude]. Irkutsk. 97 p. [in Russian]

Linev, 1900 - Linev, D.A. (1900). V peres"yl'noy tyr'me [In a transit prison]. SPb. 350 p. [in Russian]

Mulukaev i dr., 2005 - Mulukaev, R.S., Malygin, A.Ya., Epifanov, A.E. (2005). Istoriya otechestvennyh organov vnutrennih del [History of domestic law enforcement bodies]. Uchebnic dlya vuzov. M. 335 p. [in Russian]

Mulukaev, 1964 - Mulukaev, R.S. (1964). Policiya I tyremnye uchrezhdeniya dorevoluzionnoy Rossii [Police and prisons of pre-revolutionary Russia]. M. 28 p. [in Russian]

Nikitin, 1880 - Nikitin, V.N. (1880). Tyr'ma i ss"ylka. Istoricheskoe, zakonodatel'noe, administrativnoe i bytovoe polozhenie zakluchennyh, peresyl'nyh, ih detey i osvobozhdennyh iz pod straghi, so vremeni vozniknoveniya russkoiy tyr'my do nashih dney [Prison and exile. The historical, legislative, administrative and everyday situation of prisoners, transitory people, their children and those released from custody, from the time of the Russian prison to the present day]. 1560-1880. SPb. 674 p. [in Russian]

Nikolaevskiy, 1898 - Nikolaevskiy, N. (1898). Tyr'ma i ss"lka. Ocherki politicheskoy I religioznoy ss"lki [Prison and exile. Essays on political and religious exile]. M. 201 p. [in Russian]

Obshchaya..., 1916 - Obshchaya tyuremnaya instrukciya. Utverzhdena Ministrom yusticii 28 dekabrya 1915 g. [General Prison Instruction]. Pg., 1916. [in Russian]

Organy..., 1996 - Organy i vojska MVD Rossii. Kratkij istoricheskij ocherk. [Bodies and troops of the Ministry of Internal Affairs of Russia. A brief historical sketch] M., 1996. [in Russian] 
Otchyot, 1904 - Otchyot po Glavnomu tyuremnomu upravleniyu za 1902 god [General Prison Administration Report 1902]. SPb. 1904. [in Russian]

Pertli, 2011 - Pertli, L.F. (2011). Organizacionno-pravovye osnovy usloviy soderzhaniya zakluchennyh $\mathrm{v}$ dorevolucionnoy Rossii [Organizational and legal foundations of the conditions of detention of prisoners in pre-revolutionary Russia]. pod nauch. red. S.I. Kuz'mina. M. 200 p. [in Russian]

Poznyshev, 1915 - Poznyshev, S.V. (1915). Ocherki tyr'movedenya [Essays on Prison Science]. M. 295 p. [in Russian]

Pravila..., 1904 - Pravila o sodershanii v tyr'mah grazhdanskogo vedomstva politicheskih arestantov. [Rules for the detention in prisons of the civilian department of political prisoners]. SPb. 1904. $13 \mathrm{p}$. [in Russian]

Pushkin, 1841 - Pushkin, A.S. (1841). Sochineniya [Essays]. V 11 t. T. 9. SPb. 121 p. [in Russian]

Rasskazov, Uporov, 1999 - Rasskazov, L.P., Uporov, I.Ya. (1999). Tyremnye instrukcii v Rossiyskoiy imperii [Prison instructions in the Russian Empire]. Krasnodar. 57 p. [in Russian]

Sbornik..., 1911 - Sbornik cirkulyarov, izdannyh po Glavnomu tyuremnomu upravleniyu v 1879-1910 gg [Collection of circulars issued by the General Prison Administration in 1879-1910]. Ch. 1. SPb. 1911. [in Russian]

Svod..., 1890 - Svod zakonov Rossijskoj imperii. Tom chetyrnadcatyj. Ustavy o pasportah, o preduprezhdenii prestuplenij, o cenzure, o soderzhashchihsya pod strazhej, i o ssyl'nyh [Code of laws of the Russian Empire. Volume fourteenth. Charters on passports, on crime prevention, on censorship, on detainees, and on exiles]. SPb., 1890. [in Russian]

Senchenko, 1963 - Senchenko, I.A. (1963). Revolucionery Rossii na Sahalinskoy katorge [Revolutionaries of Russia in the Sakhalin penal servitude]. Yuzhno-Sahalinsk. 191 p. [in Russian]

Sibileva, 2018 - Sibileva, A.Yu. (2018). Pravovye osnovy deyatel'nosti tyrem v Tavricheskoy gubernii

(konec XVIII - nachalo XX vv.) [The legal basis for the activities of prisons in the Tauride province (late 18th - early 20th centuries)]. Simferopol'. 251 p. [in Russian]

Sizov, 1928 - Sizov, S.K. (1928). Dorevolucionnaya tyr'ma i sovetskiy ispravinel'no-trudovoy dom [Pre-revolutionary prison and Soviet correctional labor house]. Armavir, 22 p. [in Russian]

Smolyakov, 1979 - Smolyakov, V.G. (1979). Tyremnaya Sistema dorevolucionnoy Rossii, ee reactionnaya sushnost' [The prison system of pre-revolutionary Russia, its reactionary nature]. M. 23 p. [in Russian]

Sobranie..., 1890 - Sobranie uzakonenij i rasporyazhenij pravitel'stva № 49 ot 22 maya $1890 \mathrm{~g}$. [Collection of legalizations and orders of the government No. 49 of May 22, 1890]. [in Russian]

Sushickij, 1933 - Sushickij, V. (1933). Saratovskie tyur'my. [Saratov prisons]. Izvestiya Saratovskogo Nizhne-Volzhskogo instituta kraevedeniya. 3 apr. [in Russian]

Tagancev, 1902 - Tagancev, N.S. (1902). Russke ugolovnoe parvo. Chast' obshaya: lekcii N.S. Taganceva. 2-e isd-e, peresmotrennoe i dopolnennoe [Russian criminal law. General part: lectures by N.S. Tagantseva. 2nd edition, revised and supplemented]. SPb. 256 p. [in Russian]

Tyuremnyi vestnik, 1910 - Tyuremnyj vestnik. 1910. № 3. P. 321 p. [in Russian]

Tyuremnyi vestnik, 1916 - Tyuremnyj vestnik. 1916. № 6-7. 574 p. [in Russian]

Foinickiy, 1884 - Foinickiy, I.Ya. (1884). Kurs russkogo ugolovnogo sudoproizvodstva, sostavlennyi po lekcijam professor S.P. Burgskogo universiteta I.Ya. Foinickogo i izdannyi v rukovodstvo slushatelyam 1883 - 1884 goda [A course on Russian criminal justice, based on the lectures of Professor S.-P. Burg University I. Ya. Foinitsky and published as a guide to listeners in 1883-1884]. T. 2. SPb. 664 p. [in Russian]

Haziahmetov, 1978 - Haziahmetov, E.Sh. (1978). Sibirskaya politicheskaya ss'lka 1905-1917 gg.: Oblik, organizaciya, revolucionnye svjazi. [Siberian Political Exile 1905-1917: Appearance, Organization, Revolutionary Ties]. Tomsk. 183 p. [in Russian]

Yadrincev, 1872 - Yadrincev, N.M. (1872). Russkaya obshina v tyr'me i ss'lke [Russian community in prison and exile]. SPb. 719 p. [in Russian]

\section{Из истории обеспечения прав заключенных в тюрьмах Российской империи на рубеже XIX-XX вв. (по материалам Саратовской губернии)}

Александр Егорович Епифанов a , b, *, Павленко Евгения Михайловна а

a Московский городской педагогический университет, Российская Федерация

b Волгоградский институт управления - филиал Российской академии народного хозяйства и

государственной службыпри Президенте Российской Федерации (РАНХиГС), Российская Федерация

\footnotetext{
${ }^{*}$ Корреспондирующий автор

Адреса электронной почты: mvd_djaty@mail.ru (А.Е. Епифанов),

PavlenkoEM@mgpu.ru (E.M. Павленко)
} 
Аннотация. На протяжении нескольких столетий формирование культуры прав человека в России сталкивается с трудностями, преодолеть которые возможно лишь с опорой на глубокий анализ исторического развития представлений о правах человека в российском обществе. Важным этапом такого развития стал рубеж конца XIX - начала XX вв., однако из-за отсутствия в указанный период целостной концепции прав человека изменения в представлениях о достоинстве личности, ее правах и свободах находили отражение в первую очередь в нормативных правовых актах, ориентированных на практическое применение в конкретных ситуациях. Система исполнения наказаний, требующая максимально подробной регламентации своей деятельности, представляет собой объект, на примере которого изменения представлений о личности особенно заметны. В статье с историко-правовых позиций раскрываются регламентация и практика обеспечения прав заключенных российских пенитенциарных учреждений на рубеже XIX-XX вв. на примере Саратовской губернии, при этом сделан акцент на права человека «второго поколения», которые во второй половине XIX в. приобрели в России особую актуальность. Статья подготовлена на основе обширной литературы, а также ведомственных нормативных актов и архивных материалов, многие из которых введены в научный оборот впервые. В работе используются общенаучные (анализ, синтез, диалектический метод научного познания, системный подход) и частнонаучные (исторический) методы исследования. Сделан вывод, что указанный период, несмотря на конкретно-исторические условия социально-экономического, управленческого и ценностного характера, характеризуется углублением и развитием в российском обществе представлений о правах человека и ответственности государства за их соблюдение.

Ключевые слова: права заключенных, арестанты, осужденные, Главное тюремное управление, тюремные комитеты, Российская империя, Саратовская губерния. 